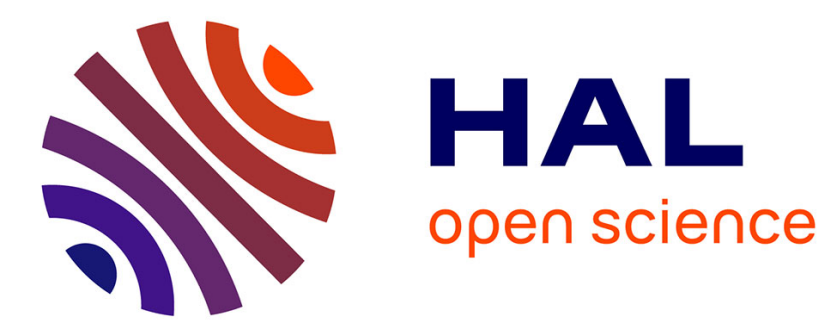

\title{
Of supermarkets and medical science: getting the product lines right
}

\author{
Jonathan Laurence Rees
}

\section{To cite this version:}

Jonathan Laurence Rees. Of supermarkets and medical science: getting the product lines right. International Journal of Clinical Practice, 2010, 64 (9), pp.1176. 10.1111/j.1742-1241.2010.02407.x . hal-00555328

\section{HAL Id: hal-00555328 \\ https://hal.science/hal-00555328}

Submitted on 13 Jan 2011

HAL is a multi-disciplinary open access archive for the deposit and dissemination of scientific research documents, whether they are published or not. The documents may come from teaching and research institutions in France or abroad, or from public or private research centers.
L'archive ouverte pluridisciplinaire HAL, est destinée au dépôt et à la diffusion de documents scientifiques de niveau recherche, publiés ou non, émanant des établissements d'enseignement et de recherche français ou étrangers, des laboratoires publics ou privés. 


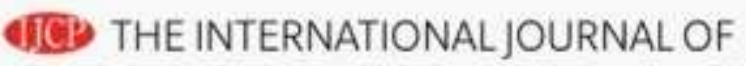 CLINICAL PRACTICE}

\section{Of supermarkets and medical science : getting the product lines right}

\begin{tabular}{|r|l|}
\hline Journal: & International Journal of Clinical Practice \\
\hline Manuscript ID: & IJCP-02-10-0096.R1 \\
\hline Manuscript Type: & Perspective \\
\hline Date Submitted by the \\
Author: & 16-Feb-2010 \\
\hline Complete List of Authors: & Rees, Jonathan; The University of Edinburgh, Dermatology \\
\hline Specialty area: & \\
\hline
\end{tabular}

\section{今 ScholarONE \\ Manuscript Central}


Of supermarkets and medical science : getting the product lines right

Jonathan L Rees FRCP,FMedSci

Dermatology, University of Edinburgh.

postal address

Dermatology, Rm. 4.018

First Floor, Lauriston Building, Lauriston Place

Edinburgh ЕH3 9HA

t: 01315362041

jonathan.rees@ed.ac.uk

Tuesday, 16 February 2010 revision 1, after comments from reviewers 
From planning, through obtaining funding, to enrolling patients and reporting results, the modern RCT is now primarily a logistical exercise. From the moment you carry out any meaningful power calculations, you have left imagination and serendipity behind. You, metaphorically, turn the crank, and out comes estimates of effect at a specified level of uncertainty: it is largely management- probability management [1]. As a statistician colleague once confided to me, his consulting (statistical) practice owed little to science or discovery, but was akin to what clinicians did in clinic: it required training, diligence, and professionalism, and the results were worthwhile. He just didn't think you should submit such activity as part of any measure of research output. We acknowledge the genius of the famous statisticians Sir Ronald Fisher and Jerzy Neyman but we don't pretend we are engaged in the same sort of activity when we use those statistical tools developed by them.

What is true of the RCT is true of much observational and survey based medical research. From funding through to analysis, the exercise can be encapsulated in a spreadsheet. More importantly, the success or otherwise of the study can also be assessed within the same accountancy spreadsheet framework as a commercial contract. If the study fails, it either shouldn't have been funded, or the investigating team have failed to deliver on what was promised, and should be censured if they bid for more contracts at a later date. Without any irony, those undertaking such studies rest their own professional futures on the tools of their own trade.

The mechanical (and useful) knowledge generation described above does not rest well with our knowledge of how great science is done. When we think of beta blockers or $\mathrm{H} 2$ antagonists, we remember not the names of 


\section{Innovation: what we know about what we don't know}

Much has been written about the nature of fundamental discovery, and almost as much has been written feigning ignorance of what we do know about it [3] [4]. First, we know major advance is rare [6]. The probability of major advance for any single scientist is low; if we want to increase the odds we need more individuals, not clones or flow diagrams $[6][7]$. Second, almost by definition, great science means that the consensus is wrong. And with this consensus comes the deadening influence of peer review [8]. Peer review will either echo the consensus or, when it is perhaps least harmful (except at a personal level), result in your ideas being stolen by competitors (for an almost forensic dissection of such see events see Roy [9]). Third, great imagination is mostly a property of individuals not large teams [7]. This isn't to deny the importance of milieu, environment is clearly critical, nor to exclude the need for collaboration or piggy-backing on the work of others, but simply that great ideas are 'so crazy' (to use Neils Bohr's words) or the path so tortured that few are likely to want to waste their time agreeing with you. Fourth, unless you are extremely lucky and able, you 
will mostly be seen to be wasting your time. It would seem self-evident—but clearly isn't judging by so much of what is written about medical research — that these criteria do not lend themselves to modern corporate ideas about accountability or value for money. But then again, science is a lot older and more disruptive than the modern corporation.

The exact mix of skills and activities needed for fundamental advance in medicine is perhaps broader than often considered for much other science-it is not just a matter of translating biochemistry or molecular biology to the clinic although this pathway receives the lions share of attention from the biomedical community [10] [11]. Pure concentrated thought of the sort involved in Andrew Wyles' solving of Fermat's Last Theorem also seems rare. On the other hand the idea that agents without nucleic acids are infectious (i.e. prions) requires not just a bold leap of imagination, but navigation around a myriad of technical traps that lead to fame on one side and ignominy on the other. Introduction of new tools and procedures, think transplantation, in vitro fertilisation or modern cataract surgery, requires first the vision and then the ability to traverse a long series of obstacles, both technical, as well as the ones imposed by one's peers as they try to adapt to a changed clinical landscape. Finally, how on earth can anybody prospectively promise they are going to describe an as yet undescribed syndrome (think HIV/AIDS or Lyme disease) or make any novel clinical observation, let alone pretend to know how useful that observation will be? [12]

Scientists are fond of remembering the battle between Galileo and the Catholic church. And with reason too. The importance of the dispute was not just about the orbits of the heavens but rather a confrontation between institutional power on the one hand and the necessity to allow individuals to hold independent views. Ever since, science and universities have striven with varying success to insulate independence of thought from everyday censure. In science the only worthwhile test, is the test in reality, not an appeal to the majority nor-and here is the rub - to the beliefs of those who pay the bills. Understanding this distinction is really critical if we want genuine clinical advance of the sort that great science produces. If you want to determine the pattern of health of a large number of persons following a health intervention, an exercise that might cost hundreds of millions of pounds, you want to leave little to chance. If you specify what you want, then by definition you do not need independence of thought, you require a contract with an entity to provide said service that will deliver the work in a timely manner according to standardised protocols. If on the other hand, you do not know what exactly you want, but just that you want the future to be different from the past, then what you need is imagination and with that comes the necessity for independence - and what independence 
really means in practice is the absence of censure and scrutiny. What seems obvious is that the structures that assess and regulate contracts cannot be the same as those that promote independence of thought-medicine requires both bold thinking and more routine assessment of treatment effects.

\section{Some suggestions}

The importance of thinking about what sort of activities lead to medical advance is timely. Health care is expensive and increasingly a drag on the wealth of nations. Despite more money being spent on medical research than ever before, many believe the golden age of medical discovery is over $[11][13][14]$. This might be because the low hanging fruit has already been taken — a comforting belief but one that may not be justified. Alternatively, it seems possible that the way science is funded and assessed has led to a diminution of novel ideas. It is fast becoming acceptable in polite company to admit that current funding streams from say the Wellcome Trust or the NIH are not 'working' - what is often being encouraged is pedestrian and safe, rather than high risk-high reward medical research [15]. How can the situation be improved? I would make two suggestions, one easy to implement, the other less so.

First, those who require contract work need to use appropriate terminology. If the NHS wants to fund large clinical trials, call them, as has been done in the past, health technology assessment. This is an accurate terminology. Do not include such activity in attempts to manipulate research in the University system by classifying them as research. Bluntly, including such activity in the like of the Research assessment exercise in the UK is like Glaxo Smith Kline demanding Higher education funds because they undertook some clinical trials. The same can be said for studies of drug side effects and other forms of population surveillance. Pay the contract price and if there is a shortage of contractors raise the price and let the market take care of the rest. Over long periods of time the need for such work is unlikely to diminish.

Having demarcated some forms of useful knowledge generation that entail little intellectual risk, the trickier problem is how to encourage bold thinking in the rest of a system that has become increasingly cautious [6] [14]. Scientists and institutions are increasingly risk averse, for the fairly obvious reason that that is what the current system of funding encourages. Following the great themes of the day (gene therapy, stem cell biology, various shades of 'omics) is a more stable financial strategy for institutions than attempting to 'solve' disease $[10]$. If success is measured by proxy measures such as grant income or publication impact, rather than the diminishing of the burden of disease, then institutions by their nature will follow the more conservative path, as it is more predictable and leaves them less financially exposed. Resolving this problem means weakening 
the chains of accountability of what academics do with their time beyond clinical practice and teaching, an idea that is unlikely to appeal to bureaucrats or politicians because it seems like a self-serving justification for idle curiosity. There is a great irony here. If we want to encourage the seeds of imagination and innovation the best we can do is provide the right soil — and wait. The last thing we should be doing is endlessly pulling up the young seedlings in order to assess how strong they are in the interests of estimating our return on investment [16]. 
1 Shuster S (2002) Treating seasonal allergic rhinitis. Well designed experiments should have been used. BMJ 324: 1277.

2 Bass A (1994) Billion-dollar drugs. In: Reinventing the future : conversations with the world's leading scientists. Reading, Mass.: Addison-Wesley Publishing Co.,Inc.. pp. 48.

3 Ziman J (2000) Real science. Cambridge: Cambridge University Press.

4. Ziman J (1999) Rules of the game of doing science. Nature 400: 721.

5 Mullis (1999) Dancing Naked in the Mind Field. Bloomsbury.

6 Braben W (2008) Scientific Freedom: The elixir of civilization. WileyBlackwell.

7 Bronowski (1977) A sense of the future : Essays in Natural Philosophy. Cambridge Mass.: MIT Press.

8 Horrobin DF (1996) Peer review of grant applications: a harbinger for mediocrity in clinical research?

Lancet 348: 1293.

9 Roy R, Ashburn JR (2001) The perils of peer review. Nature 414: 393-394.

10 Rees JL (2002) Complex Disease and the New Clinical Sciences. Science 296: 698.

11 Rees JL (2004) The fundamentals of clinical discovery. Perspect Biol Med 47: 597.

12 Goldstein JL, Brown MS (1997) The clinical investigator: bewitched, bothered, and bewildered--but still beloved. Journal of Clinical Investigation 99: 2803.

13 Charlton BG, Andras P (2008) Down-shifting among top UK scientists? - the decline of 'revolutionary science' and the rise of 'normal science' in the UK compared with the USA. Med Hypotheses 70: 465-472. 14. Charlton BG (2008) Zombie science: a sinister consequence of evaluating scientific theories purely on the basis of enlightened self-interest. Med Hypotheses 71: 327-329.

15 Nurse P (2006) US biomedical research under siege. Cell 124: 9-12.

16 Bronowski (1978) The Origins of Knowledge and Imagination. New Haven: Yale University Press. 
